\title{
ELEKTRONIC EDUCATIONAL MATERIALS OF PROFESSIONAL SUBJECTS IN THE CONTEXT OF INFORMATION AND COMMUNICATION COMPETENCIES
}

\author{
Marek EL ̌́SÍK - Mária VARGOVÁ
}

\begin{abstract}
The article deals with the creation, placement and use of electronic learning materials for vocational subjects in secondary education degree courses. Creating electronic materials that are placed on the website of the school pupils in particular facilitate the domestic preparation, allowing the materials to work independently and to anywhere from anywhere, as it is accessible to the network. They are one of the tools of active learning and the acquisition of IT skills.
\end{abstract}

Key words: competencies, elektronic educational materials, pupil, information and communication technologies.

\section{ELEKTRONICKÉ VZDELÁVACIE MATERIÁLY ODBORNÝCH PREDMETOV V KONTEXTE INFORMAČNÝCH A KOMUNIKAČNÝCH KOMPETENCIÍ}

Resumé: Príspevok sa zaoberá problematikou vytvárania, umiestňovania a použivania elektronických vzdelávacích materiálov odborných predmetov $\mathrm{v}$ rámci študijných odborov stredoškolského vzdelávania. Vytvorené elektronické materiály, ktoré sú umiestnené na webovej stránke školy, ul'ahčujú žiakom najmä domácu prípravu, umožňujú s materiálmi pracovat' samostatne a to kdekolvvek a odkial'kol'vek, pokial' je prístupná internetová siet'. Sú jedným z nástrojom aktívneho učenia sa a osvojovania si informačných kompetencií.

Klíčová slova: kompetencie, elektronické vzdelávacie materiály, žiak, informačné a komunikačné technológie.

\section{1 Úvod}

Aplikovanie informačno - komunikačných technológií (IKT) do procesu edukácie prináša zo sebou zefektívnenie, skvalitnenie a modernizáciu možností a spôsobov ich využívania $\mathrm{v}$ rámci l'ubovol'ného vyučovacieho predmetu. Príprava a tvorba vzdelávacích materiálov v elektronickej forme je v súčasnosti skôr dominanciou vysokých škôl a univerzít. Avšak rovnako dôležité je, aby elektronické vzdelávacie materiály mali k dispozícii aj žiaci stredných škôl, predovšetkým stredných odborných škôl. Je faktom, že s nástupom reformy školstva $v$ rokoch 2008/2009 sa každoročne stretávame s nedostatkom učebníc. Rovnako je faktom, že väčšina učebníc je určená pre žiakov základných škôl a gymnázií, teda ide predovšetkým o všeobecno - vzdelávacie učebnice, pričom odborné učebnice dlhodobo chýbajú. Sme toho názoru, že by bolo potrebné zamerat' sa na tvorbu elektronických študijných materiálov, ktoré sú výraznou pomôckou pre žiakov. A to nielen $\mathrm{v}$ čase vyučovania, ale aj $\mathrm{v}$ čase mimo vyučovania, teda $\mathrm{v}$ čase samoštúdia žiakov. Dnes, v dobe prudkej internetizácie spoločnosti sa internet a prostriedky IKT stávajú súčastou takmer každej domácnosti. To poskytuje lepší a zároveň aj jednoduchší prístup k elektronickým vzdelávacím materiálom.

\section{IKT kompetencie vo vzdelávaní}

V súčasnosti sa dostáva výrazne do popredia otázka vzdelania, vzdelávania, gramotnosti človeka v kontexte jeho prípravy na život, aktívneho a úspešného spoločenského uplatnenia, kvalitného profesijného, či osobného života. Preto je nevyhnutné poznat' odpoved' na otázku: čo je aktuálnym obsahom gramotnosti človeka, a ktoré vedomosti, zručnosti a schopnosti by mal mat' gramotný človek $\mathrm{v}$ súčasnej dobe. $\mathrm{V}$ dnešných podmienkach a nárokoch na človeka, $\mathrm{v}$ dobe rozvoja informačnej spoločnosti a IKT je klúčovou kompetenciou moderného človeka kompetencia informačná. V rámci informačnej kompetencie rozlišujeme gramotnost':

- „informačnú,

- počitačovú, 
- digitálnu gramotnost"“ (Šušol Hrdináková - Rankov, 2005).

„Informačná gramotnost' je schopnost jednotlivcov použivat' informačné zdroje pri práci, riešení problémov a to tak, že sa naučia využivat' širokú škálu techník a informačných nástrojov, ako i primárne zdroje" (Dombrovská -Landová - Tichá, 2004).

Počítačová gramotnost' je schopnost' pracovat' s najčastejšie využívaným programovým vybavením, schopnost' používat' internet pri komunikácii, k vyhladávaniu a spracovaniu informácií, schopnost' efektívneho využitia služieb a možností, ktoré moderná technológia ponúka.

Digitálna gramotnost' podl'a Hrma a Tureka (2003) „je súbor vedomostí, zručností a postojov obsahovo zameraných na využivanie technológii informačnej spoločnosti na prácu, volný čas a komunikáciu“.

Nadpriemernými informačno - komunikačnými kompetenciami by mali dnes, v 21. storočí, disponovat' aj učitelia. Nestačí totiž, ak pedagóg používa iba bežné kancelárske balíky, ale je rovnako nevyhnutné, aby bol schopný pracovat' s multimédiami a rôznymi špecializovanými programami. Pedagóg musí byt' schopný nájst', zhromažd'ovat' a triedit' informácie $\mathrm{z}$ internetu. Implementácia IKT do vyučovania je podmienená okrem iného aj zmenou učebných osnov predmetov a teda aj obsahu vyučovania. Moderné IKT nemenia totiž iba spôsob ako učit', ale tiež obsah, ktorý treba učit'. Elektronické vzdelávacie materiály patria $\mathrm{k}$ nevyhnutným a najdôležitejším nástrojom implementácie IKT do edukačného procesu. Prvoradým ciel'om evzdelávania je inovovat' formu prezentovania učiva prostredníctvom moderných technológií. Celý proces integrácie IKT do vyučovania kladie vysoké nároky na učitel'a, pretože sa od neho vyžaduje, aby:

- „optimálnym spôsobom využival moderné IKT a to tak, aby dosahoval vytýčené vzdelávacie ciele predmetu,

- primeraným spôsobom rozvijal informačnú gramotnost' žiakov,

- naučil žiakov pracovat' samostatne a efektivne s prostriedkami IKT,

- neustále upozorňoval na vztah IKT človek, človek - IKT,

- rozvijal dôveru žiakov v použivani IKT prostrednictvom častého precvičovania " (Paris, 2004).
3 E - materiály vytvorené a používané učitel'mi odborných predmetov na SOŠ elektrotechnickej $v$ Trnave

Požiadavku vytvorit' elektronický vzdelávací obsah iniciovala predmetová komisia odborných predmetov informatických, matematiky a fyziky na Strednej odbornej škole elektrotechnickej v Trnave. Skupina učitel'ov odborných predmetov intenzívne začala pracovat' na elektronických vzdelávacích materiáloch pre denných študentov, pre študentov študujúcich podl'a individuálneho vzdelávacieho plánu (IVP) a študentov externej formy štúdia. Prvoradou úlohou e-vzdelávacieho materiálu je zrozumitel'nost', teda napísaný tak, aby akceptoval vedomostnú úroveň žiakov, pre ktorých je určený. Rovnako dôležitý je nielen metodický postup jeho tvorby, ale aj interaktívnost' vzdelávacieho materiálu, aby sa mohol stat' vhodným motivačným a didaktickým prostriedkom pre samoštúdium. E-vzdelávacie materiály sú určené najmä žiakom študujúcich odbor $3447 \mathrm{~K}$ grafik digitálnych médií, $2682 \mathrm{~K}$ mechanik počítačových sietí alebo pre žiakov iných foriem štúdia (externá, IVP), prípadne príbuzné odbory. V súčasnosti sú e-vzdelávacie materiály umiestnené na webstránke školy a sú spracované a vytvorené pre 1. a 2. ročník oboch odborov. Učitel'ský tím intenzívne pracuje na študijných textoch tak, aby v blízkej budúcnosti doplnil aj ostatné ročníky, čím výrazne pomôže žiakom pri ich príprave na budúce povolanie. Evzdelávacie materiály sú vol'ne prístupné aj širokej verejnosti na URL adrese: http://www.sose-

trnava.edu.sk/teachers/ipb/2013/index.html

(Obr. 1)

Obr. 1: Ukážka úvodnej webstránky

Po načítaní úvodnej stránky sa vzdelávajúci subjekt môže rozhodnút', ktorý predmet a tému si




potrebuje osvojit', precvičit'. Klikne na zvolený výber a zobrazia sa mu jednotlivé okruhy $\mathrm{v}$ rámci daného ročníka (Obr. 2).

Obr. 2: Po kliknutí na položku Flash

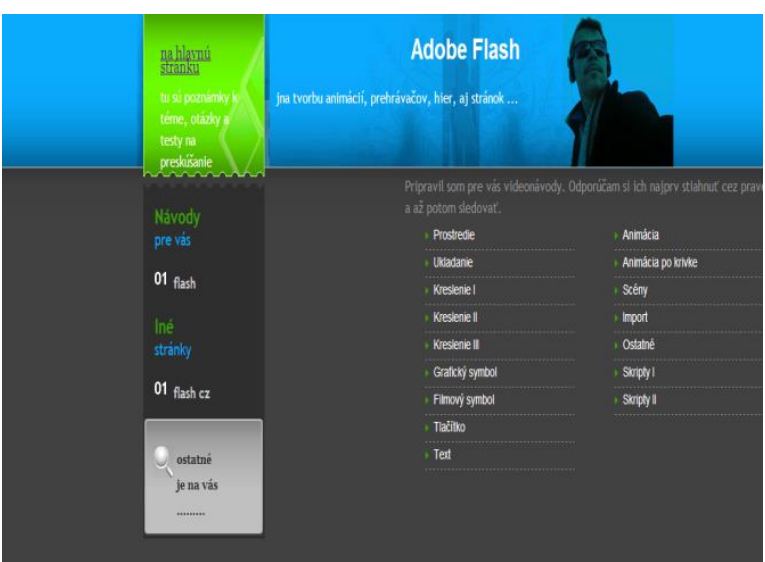

Ak sa rozhodne, že si zo zvolených okruhov potrebuje osvojit' poznatky a zručnosti z tvorby grafických symbolov vo Flashi, jednoducho klikne na danú položku a zobrazí sa mu multimediálne video s komplexným postupom tvorby (Obr. 3).

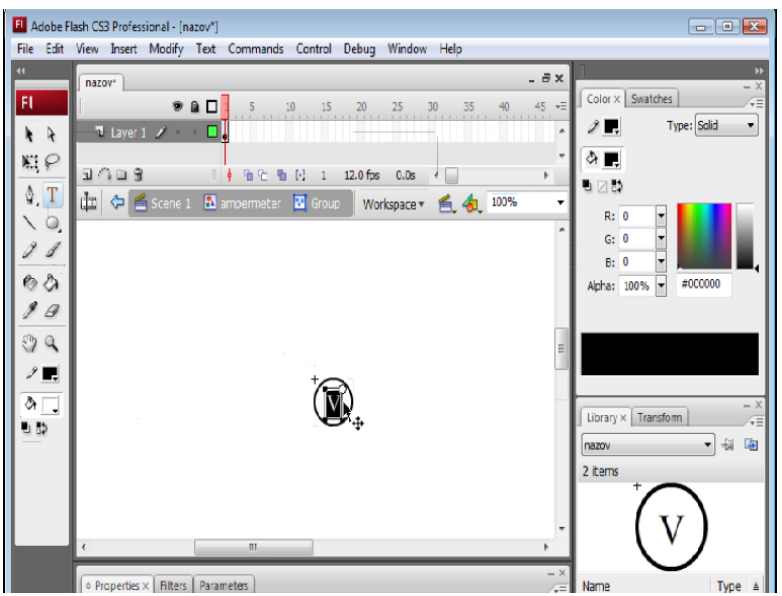

Obr. 3: ukážka tvorby grafického symbolu voltmetra

Záujemcovia o vzdelávanie takouto formou majú $\mathrm{k}$ dispozícii nielen teoretické elektronické vzdelávacie materiály, ale rovnako majú $\mathrm{k}$ dispozícii aj multimediálne video, kde sa prakticky môžu naučit' vytvárat' rôzne grafické symboly, prvky, animácie a pod. Vytvorené elektronické vzdelávacie materiály umiestnené na webstránke školy sú jednou z možností zvyšovania kvality vzdelávania žiakov na SOŠ. Je predpoklad, že zaradením IKT a inovačných foriem vzdelávania do vzdelávacieho procesu sa príprava mladých l'udí skvalitní. „, Tento proces je potrebný a dôležitý zhl'adiska uplatnenia absolventa stredných škôl na trhu práce" (Vargová, 2010).

Ak vyučujúci využije e-vzdelávacie materiály na vyučovacej hodine, podporí tým u žiakov záujem o predmet a preberanú látku, zatraktívni edukačný proces.

Ďalšou úlohou, ktorá čaká učitel'ský tím, učitel'ov na SOŠ elektrotechnickej v Trnave, je aplikovat' systém LMS Moodle, ktorý by výrazne podporil praktickú realizáciu on - line vzdelávacích modulov, kurzov a zároveň by umožnil aj on-line overenie vedomostí.

\section{Záver}

Informačné a komunikačné kompetencie sú neoddelitel'nou a neodmyslitel'nou súčast'ou moderného a kvalitného učitel'a. Učitel'a schopného vytvárat' elektronické vzdelávacie materiály. Uvedené ukážky e-vzdelávacích materiálov z odborných predmetov pre žiakov SOŠ elektrotechnická Trnava, sú vhodným a kvalitným študijným materiálom nielen na štúdium počas vyučovania, ale aj na vzdelávanie sa v čase mimo vyučovania, pomôžu žiakom pri príprave na testy a praktické cvičenia. Majú svoje výhody. $\mathrm{K}$ e-vzdelávacích materiálov má žiak prístup kedykol'vek, kdekol'vek a odkial'kol'vek. Materiály zatraktívňujú edukáciu a svojou interaktivitou umožňujú zásah do e- materiálu (zastavenie, pretočenie videa a pod.)

\section{Literatúra}

1. DOMBROVSKÁ, M., LANDOVÁ, H., TICHÁ, L. 2004. Informační gramotnost teorie a praxe $\mathrm{v} \check{C} \mathrm{R}$ [online]. In Národní knihovna: knihovnická revue, roč. 15, 2004, č.1, s. 7-18 [cit. 2013-08-12]. Dostupné na internete:

<http://full.nkp.cz/nkkr/NKKR0401/0401007. html>.

2. HRMO, R. - TUREK, I. 2003. Kl'účové kompetencie I. Bratislava: STU. 2003. 179 s. ISBN 80-227-1881-5.

3. KUČERKA, D. - HRMO, R. 2012. Rozvoj informačnej kompetencie prostredníctvom elearningu. Trendy vo vzdělávání. Informačni technologie a technické vzdelávání. UP Olomouc, ČR, 20. - 21. června 2012, s. 640650. ISBN 978-80-86768-36-6.

4. PARIS, P.G. E-learning: A study on Secondary Students Attitudes towards Online 
Web Assisted Learning. International Education Journal, 2004, vol. 5, s. 98 - 112.

5. ŠUŠOL, J. - HRDINÁKOVÁ, L'. RANKOV, P. 2005. Informačné a komunikačné technológie vo vzdelávaní.1. vydanie. Bratislava 2005. 152 s. ISBN 8088982-97-9.

6. VARGOVÁ, M. Technické vzdelávanie a trh práce. Nitra: PF UKF, 2010. 124 s. ISBN 97880-8094-829-0. doc. PaedDr. Mária Vargová, PhD.

Teoretická studie

Katedra techniky a informačných technológií

Pedagogická fakulta UKF

Dražovská cesta 4

94974 Nitra

E-mail: mvargova2@ukf.sk

Www pracoviska: www.ktit.pf.ukf.sk

PaedDr. Marek Elšík

Stredná odborná škola elektrotechnická

Sibírska 1

91701 Trnava

E-mail: marek.elsik@ukf.sk

Www pracoviska: www.sose-trnava.edu.sk 